\title{
An Investigation \\ Into Nigerian Teachers' Knowledge Of Primary Science Curriculum Content And Involvement In Practical Activities: Implications For The UBE Scheme
}

\author{
Ayodele. O. Ogunleye, University of Lagos, Nigeria
}

\begin{abstract}
The study was designed to find out the extent of Nigerian teachers' knowledge of primary science curriculum content and their involvement in the participation of their pupils in science activities. Furthermore, the study sought to find out teachers ranking of primary science objectives. The subjects were 60 primary school teachers randomly selected from both urban and rural primary schools in Lagos State. A questionnaire constructed by the researcher, whose coefficient of internal validity was 0.85 , was used for data collection. The findings of the study show that a significant proportion of primary school teachers experience difficulty in teaching many of the topics of the primary science curriculum. Further findings of the study were discussed with regards to qualification, Sex and experiences of teachers. The implications of these findings for the Nigeria Universal Basic Education (UBE) scheme were also highlighted.
\end{abstract}

Keywords: Primary science curriculum, science activities, manipulative skills, science objectives.

\section{INTRODUCTION}

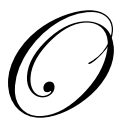

ne major focus in which there were a lot of curriculum development activities the world over has been in the area of primary science. Pupils understanding of the nature of science and the development of positive attitudes towards science are some of the important objectives of science education. Recent calls for reform in science education have also emphasized the need for it to be accessible to all students and for students to attain high levels of scientific literacy (American Association for the Advancement of Science, 1993; National Research Council, 1996). The capacity to conceptualize and teach the subject matter by making it accessible to learners is therefore critical to teachers work. Bransford et al (2005) were of the opinion that to make content accessible to learners, teachers need flexible understanding of the subject matter coupled with an appreciation for how students learn. This challenge today confronts all primary school teachers. In fact, the issue of one of the teachers' knowledge has been accepted as one of the aspects of improving educational practices (Poulson, 2001). This view agrees with that of Cochran-Smith \& Lytle (1999) who said, "teachers who know more teach better".

In Nigeria, the enthusiasm to promote primary science started as far back as the late 1960s. At both National and State levels, various curriculum packages were developed. According to Ogunleye (1999) some of the science curriculum projects developed at that time were the African Primary Science Programme (APSP) of 1965 which later became the Science Education Project for Africa (SEPA); the Bendel Primary Science Project (BPSP) of 1972; the Science Programme of the Primary Education Improvement Project (PEIP) of 1970, just to mention a few. The Nigerian National Policy on Education (NPE, 1998) was equally emphatic on promoting science; hence the emphasis was to ensure that science education must start from the grassroots. According to the policy, in order to lay 
a sound basis for scientific and reflective thinking and also to develop manipulative skills, science education should enable the child to:

- $\quad$ Observe and explore the environment

- $\quad$ Develop basic science process skills e.g observing measuring, classifying etc.

- Develop a functional knowledge of science and explain simple natural phenomena of science concepts and principles

- $\quad$ Develop a scientific attitude including curiosity, self reliance, critical kinking and objectivity

- $\quad$ Solve everyday problems in the environment and at home

In order to achieve these objectives of primary science, the policy made provision for the teaching of science as a compulsory subject at the primary school level. This was as a result of government's realization of the fact that the desire and performance of children to study science and science related subjects at subsequent other levels of their educational career is to a large extent dependent on their early experiences and exposure to science. Consequently, a new core curriculum known as the Nigeria Primary School Science and Mathematics Project (NPSSMP) was developed. To implement this new curriculum, the national policy on educational (NPE, 1998), deemphasized the memorization and regurgitation of facts, while more emphasis was placed on the practical, exploratory and experimental methods of teaching science. A critical examination of the NPSSMP curriculum showed that there was great emphasis on inquiry and process activities, i.e. "doing rather than telling". Furthermore, children should be immersed in an extended series of enriched experiences that will give them ample opportunities for self-discovery, process skills acquisition and also to develop positive attitudes towards science. According to Piaget (1966), primary school children are mostly in the concrete operational stage of their development, where most of their mental operations are directly related to exploring concrete objects of events and situations. Hence, if meaningful and effective science learning is to occur at the primary levels, it is important that teachers must present the learning materials in concrete forms.

\section{REVIEW OF LITERATURE}

Science is acknowledged as an important part of every child's education, yet in many countries, there is much evidence to suggest that primary science education is still in a parlous state (Mullholland \& Wallace, 1996). Research indicates that primary science teachers background knowledge is very fluid, with the result that many primary science teachers lack the confidence and competence to teach science effectively (Goodrum et al 2001, Osborne and Simeon, 1996). According to Harlen \& Holroyd (1997), Summers \& Kruger (1994), many primary science teachers still hold concepts that are in conflict with scientific views. In recent times however, there has been an increased emphasis on the importance of subject knowledge as a component of teacher expertise. This is particularly true in the field of primary science which requires that teachers understand both the scientific knowledge and the ways by which this knowledge can be taught successfully to children (see Summers et al, 1998). Science knowledge is a very important factor that influences primary teachers confidence in teaching science (Harlen \& Holoyd, 1997), as teachers with low confidence in themselves cope by only teaching those areas that they are familiar with, such as for example, stressing aspects of biology, and sometimes did little practical activities. According to Harley \& Holroyd (1997), Lee (1995), when these coping strategies become the norm, pupils' attainment will be limited. For this reason, Halen (2000) suggested that in order for primary school teachers to be effective, they must have a level of subject knowledge above some specified threshold. This will enable primary science teachers to have a foundation for building a framework for teaching science.

\section{RESEARCH PROBLEM}

In recent years many science educators have found that most of our primary schools do not have the equipment and materials for teachers to conduct practical activities or for children to carry out investigative activities that could enable pupils discover things for themselves (Aigbobomian 1990). According to Odor and Azeke (1986), science teaching becomes didactic, expository or story telling when equipment and materials are lacking. The question really is: do our primary school teachers possess the adequate knowledge of the science content of the curriculum and how often do they carry out the practical activities specified in the primary science curriculum? Do they try out these activities before engaging children in carrying them out? Are they sufficiently 
knowledgeable in the philosophy and objectives of primary science, as this could inevitable help in their choice and organization of appropriate learning experiences?

This study therefore sought answers to the following research questions:

1. Which primary science objectives do teachers see as important and which ones are of least importance, and will there be difference in ranking with regards to teachers' qualifications, sex and experience?

2. Which of the practical activities do primary school teachers often carry out as recommended in the primary school curriculum?

3. What proportion of primary schoolteachers has difficulty in teaching the content area of the primary science curriculum?

4. Would there be significant differences in the knowledge possessed by teachers with regards to their qualifications, sex and experience?

\section{METHOD}

Sixty primary school teachers from different schools in Lagos state who attended an in-service training course in science were the subjects for this study. The teachers were randomly selected from urban and rural primary schools from the population of teachers who attended the courses. An instrument, known as the Primary Science Teachers Assessment Inventory, was designed as the instrument for this research. It consisted of four sections. Section I sought general information about respondents qualifications, sex and teaching experiences. Section II consisted of five objectives of teaching science as contained in the National policy on Education. Teachers were asked to rank the objectives in order of importance to their pupils' leaning of science. Sections III and IV consisted of twenty-five content areas of the primary science curriculum and teachers were asked to indicate the ease or difficulty of teaching these topics and also show how often they carry out activities recommended in the primary science curriculum. Five-science education experts validated the questionnaire. They were to decide on the adequacy and comprehensiveness of the items, and for which they all agree that items in the questionnaire adequately covered the primary science content, validated the questionnaire. The instrument was later pilot - tested. Its internal validity was established by using the spilt-half technique, whereby scores on two equivalent halves of the instrument were totaled separately and the correlation coefficient calculated, whose value was later corrected by using Spearman Brown Prophecy formula. The corrected co-efficient value was 0.85. The questionnaire was later administered on the teachers. The response rate was $95 \%$.

\section{RESULTS}

The results of study and the various interpretations are given in this section.

\section{Research Question 1}

Which primary science objectives do teachers see as important and which ones are of least importance, and will there be difference in ranking with regards to teachers' qualifications, sex and experience?

The teachers ranking of the primary science objectives are given in Table. 1 The tabulation follows the order of total means for all groups (by qualifications, experience and sex) accordingly.

The results in Table.1 show that primary schools teachers are quite knowledge about the objectives of teaching primary science. The analysis of the responses for this of the questionnaire was through the use of mean scores and ranking. The means were calculated for each of the objectives such that the objectives with small mean ranks can be said to be more important than those with higher mean ranks. The results in Table 1 show that the objective "To help pupils observe and explore the environment was ranked as the most important objective in the teaching of primary science. Furthermore, the objective "To help pupils develop science process skills was ranked second. The third highly ranked objective is " To help pupils solve everyday problems in the environment and at home". Thus, one could say that the environment plays an important part in learning science at the primary school level. Further analysis of the data showed that not much difference existed between the ranking of objectives by 
teachers according to qualifications, sex and experience. However, it is important to note that teachers with B.Sc. (Ed) ranked the last two statements as the most important set of objectives.

Table 1-Rank Order of the Objectives of Teaching Science by Primary School Teachers

\begin{tabular}{|c|c|c|c|c|c|c|c|c|c|c|c|}
\hline \multicolumn{4}{|c|}{ Totals Means by qualifications } & \multicolumn{4}{|c|}{ Total means by Experience } & \multicolumn{4}{|c|}{ Total means by sex } \\
\hline AIMS & Means & $\begin{array}{l}\text { B.Sc } \\
\mathrm{N}=4\end{array}$ & $\begin{array}{l}\text { B.Sc } \\
(\mathrm{Ed}) \\
\mathrm{N}=7\end{array}$ & $\begin{array}{l}\text { N.C.E } \\
\mathrm{N}=45\end{array}$ & $\begin{array}{l}\text { Grade } \\
\text { II } \\
\mathrm{N}=4\end{array}$ & $\begin{array}{l}1-5 \\
\text { Yrs } \\
\mathrm{N}=4\end{array}$ & $\begin{array}{l}6-10 \\
\text { Yrs } \\
N=14\end{array}$ & $\begin{array}{l}11-5 \\
\text { Yrs } \\
\text { N-11 } \\
\end{array}$ & $\begin{array}{l}\text { Above } \\
15 \text { Yrs } \\
\mathrm{N}=3\end{array}$ & $\begin{array}{l}\text { Male } \\
\mathrm{N}=17\end{array}$ & Female \\
\hline $\begin{array}{l}\text { To help pupils } \\
\text { observe and } \\
\text { explore the } \\
\text { environment }\end{array}$ & $\begin{array}{l}2.32 \\
(1 \mathrm{st})\end{array}$ & $\begin{array}{l}2.00 \\
(1 \mathrm{st})\end{array}$ & $\begin{array}{l}2.57 \\
\text { (3rd) }\end{array}$ & $\begin{array}{l}2.33 \\
\text { (1st) }\end{array}$ & $\begin{array}{l}2.00 \\
(1 \mathrm{st})\end{array}$ & $\begin{array}{l}1.75 \\
(2 \mathrm{nd})\end{array}$ & $\begin{array}{l}2.3 \\
(1 \mathrm{st})\end{array}$ & $\begin{array}{l}1.91 \\
(1 \mathrm{st})\end{array}$ & $\begin{array}{l}2.52 \\
(1 \mathrm{st})\end{array}$ & $\begin{array}{l}1.82 \\
(1 \mathrm{st})\end{array}$ & $\begin{array}{l}2.51 \\
(1 \mathrm{st})\end{array}$ \\
\hline $\begin{array}{l}\text { To help pupils } \\
\text { develop science } \\
\text { process skill }\end{array}$ & $\begin{array}{l}2.58 \\
(2 \mathrm{nd})\end{array}$ & $\begin{array}{l}3.25 \\
(2 \mathrm{nd})\end{array}$ & $\begin{array}{l}3.00 \\
\text { (5th) }\end{array}$ & $\begin{array}{l}2.51 \\
(2 \mathrm{nd})\end{array}$ & $\begin{array}{l}2.00 \\
(1 \mathrm{st})\end{array}$ & $\begin{array}{l}1.7 \\
(2 \mathrm{nd})\end{array}$ & $\begin{array}{l}2.36 \\
(1 \mathrm{st})\end{array}$ & $\begin{array}{l}2.00 \\
\left(2^{\text {nd }}\right)\end{array}$ & $\begin{array}{l}3.00 \\
(4 \mathrm{th})\end{array}$ & $\begin{array}{l}2.65 \\
(2 \mathrm{nd})\end{array}$ & $\begin{array}{l}2.56 \\
(3 \mathrm{rd})\end{array}$ \\
\hline $\begin{array}{l}\text { To help pupils } \\
\text { explain simple } \\
\text { natural } \\
\text { phenomena of } \\
\text { science }\end{array}$ & $\begin{array}{l}3.02 \\
(5 \mathrm{th})\end{array}$ & $\begin{array}{l}4.00 \\
(5 \mathrm{th})\end{array}$ & $\begin{array}{l}2.71 \\
\text { (4th) }\end{array}$ & $\begin{array}{l}2.95 \\
\text { (4th) }\end{array}$ & $\begin{array}{l}3.25 \\
(3 \mathrm{rd})\end{array}$ & $\begin{array}{l}1.25 \\
(1 \mathrm{st})\end{array}$ & $\begin{array}{l}3.07 \\
\text { (3rd) }\end{array}$ & $\begin{array}{l}2.64 \\
\text { (4th) }\end{array}$ & $\begin{array}{l}3.35 \\
(5 \mathrm{th})\end{array}$ & $\begin{array}{l}2.70 \\
\text { (3rd) }\end{array}$ & $\begin{array}{l}3.14 \\
\text { (5th) }\end{array}$ \\
\hline $\begin{array}{l}\text { To help pupils } \\
\text { develop } \\
\text { scientific } \\
\text { attitudes }\end{array}$ & $\begin{array}{l}2.98 \\
\text { (4th) }\end{array}$ & $\begin{array}{l}3.75 \\
\text { (4th) }\end{array}$ & $\begin{array}{l}2.00 \\
(1 \mathrm{st})\end{array}$ & $\begin{array}{l}3.00 \\
\text { (5th) }\end{array}$ & $\begin{array}{l}3.75 \\
\text { (4th) }\end{array}$ & $\begin{array}{l}2.25 \\
(4 \mathrm{th})\end{array}$ & $\begin{array}{l}3.78 \\
(5 \text { th) }\end{array}$ & $\begin{array}{l}2.27 \\
\text { (3rd) }\end{array}$ & $\begin{array}{l}2.97 \\
\text { (3rd) }\end{array}$ & $\begin{array}{l}2.82 \\
(4 \mathrm{th})\end{array}$ & $\begin{array}{l}3.05 \\
\text { (4th) }\end{array}$ \\
\hline $\begin{array}{l}\text { To help pupils } \\
\text { solve everyday } \\
\text { problems in the } \\
\text { environment }\end{array}$ & $\begin{array}{l}2.90 \\
(3 \mathrm{rd})\end{array}$ & $\begin{array}{l}3.25 \\
(2 \mathrm{nd})\end{array}$ & $\begin{array}{l}2.00 \\
(1 \mathrm{st})\end{array}$ & $\begin{array}{l}2.91 \\
(3 \mathrm{rd})\end{array}$ & $\begin{array}{l}4.00 \\
(5 \mathrm{th})\end{array}$ & $\begin{array}{l}3.00 \\
\text { (5th) }\end{array}$ & $\begin{array}{l}3.14 \\
\text { (4th) }\end{array}$ & $\begin{array}{l}3.00 \\
(5 \text { th) }\end{array}$ & $\begin{array}{l}2.74 \\
(2 \mathrm{nd})\end{array}$ & $\begin{array}{l}3.82 \\
(5 \mathrm{th})\end{array}$ & $\begin{array}{l}2.53 \\
(2 \mathrm{nd})\end{array}$ \\
\hline
\end{tabular}

Table 2-Mean Scores showing extent of Teachers Involvement in Science Activities

\begin{tabular}{llll}
\hline S/N & Topics in primary science & Total mean scores & Extent of involvement \\
\hline 1 & Our environment & 3.65 & Very often \\
2 & Using the senses & 3.58 & Very often \\
3 & Air & 3.52 & Very often \\
4 & Water & 3.77 & Very often \\
5 & Food & 3.75 & Very often \\
6 & Health and safety & 3.50 & Very often \\
7 & Housing and clothing & 3.42 & Occasionally \\
8. & Animal & 3.35 & Occasionally \\
9 & Plants & 3.55 & Very often \\
10 & Grouping & 3.66 & Very often \\
11. & Ordering & 3.12 & Rarely \\
12 & Modeling and technology & 2.71 & Rarely \\
13 & Forces & 2.76 & Rarely \\
14 & Measurement & 3.47 & Very often \\
15 & Mirrors and images & 3.47 & Rarely \\
16 & Sound & 3.36 & Occasionally \\
17 & Colour & 3.52 & Very often \\
18 & Heat Energy and temperature & 3.01 & Rarely \\
19 & Weather & 3.01 & Rarely \\
20 & Huamn body & 3.42 & Occasionally \\
21 & Electric Circuit & 2.38 & Rarely \\
22 & Soap and Alkali & 2.38 & Rarely \\
23 & Simple machines & 3.26 & Occasionally \\
24 & Magnets & 3.28 & Occasionally \\
25 & Soil, rocks and minerals & 2.88 & Rarely \\
\hline
\end{tabular}




\section{Research Question 2}

Which of the practical activities do primary school teachers often carry out as recommended in the primary science curriculum?

The result of the analysis is shown in Table 2. Each item response has a weighted score and this was translated into a weighted total mean score of 3.27; thus, mean scores above 3.27 were regarded as those areas that teachers often carry out activities for their pupils, whereas topics whose mean scores are less than 3.27 indicates that primary school teachers do not perform any of the activities as recommended in the primary science curriculum. The calculated means show that the topic "Water" has the highest means. This in effect means that teachers very often involve their pupils in the recommended activities for this topical area. Other topical areas where teachers often carry out practical work include groupings, our environment, using the senses, plants, air, color, measurement, health and safety.

Since the calculated average mean for all the items is 3.37. It follows that topics whose mean are less than 3.37 indicates that primary school teachers do not carry out any of the activities as recommended in the primary science curriculum. As shown in Table 2 therefore, teachers do not involve their pupils in carrying out activities in the following topical areas in these orders.

$\begin{array}{ll}\text { 1. } & \text { Ordering } \\ 2 . & \text { Heat energy } \\ \text { 3. } & \text { Weather } \\ \text { 4. } & \text { Soil, Rock and Minerals } \\ \text { 5. } & \text { Mirrors and images } \\ \text { 6. } & \text { Forces } \\ \text { 7. } & \text { Modeling and technology } \\ \text { 8. } & \text { Electric Circuit } \\ \text { 9. } & \text { Soap and Alkali }\end{array}$

However, teachers occasionally carry out activities as recommended in the primary science curriculum for the following topical areas in this order.

$\begin{array}{ll}\text { 1. } & \text { Housing and Clothing } \\ 2 . & \text { Human body } \\ \text { 3. } & \text { Sound } \\ \text { 4. } & \text { Simple machines } \\ \text { 5. } & \text { Animal } \\ \text { 6. } & \text { Magnets }\end{array}$

It is therefore sad to remark that if teachers occasionally or do not, carry out recommended activities in fifteen out of the twenty-five topical areas of the primary science curriculum, as listed here, how then could pupils effectively learn science. These activities are those that involve the pupils in the learning process. Furthermore, such activities also assist pupil's to employ their curiosity and also develop in them the necessary process skills. The philosophy of the NPSSMP emphasizes the child exploring his environment and from it discovers science as a process and a product. The result of this study is therefore both revealing and disturbing, revealing in the sense that it indicates the type of learning experiences that teachers subject their pupils to in the process of learning science. It is disturbing in the sense that a large number of our pupils are learning no science, experiencing no science and possibly acquiring negative attitude towards science at the primary school level. It is possible for example that many schools may not have science corners, science materials or improvised items for such topics like heat energy and temperature, weather, soil, rocks, modeling and technology, electric circuit etc. 


\section{Research question 3}

What proportion of primary school teachers have difficulty in teaching the content area of the primary science curriculum?

In this section of the questionnaire, the number of teachers having the ease or difficult in teaching the content area of the curriculum were found and a $\chi 2$ statistics used to find the differences in means. This item scoring procedure and analysis helped the author to diagnose areas of weaknesses of teachers. Table 3 shows the percentage of ease or difficulty that primary schools teachers have when teaching the various concepts of the primary schools curriculum. The easiest topics for them to teach are food, water, using the senses, our environment, plants, colour, housing and clothing, air, health and safety. The following are the topics that teachers find difficult to teach; Force, Electric circuit, soap and alkali, soil, rocks and minerals, Heat Energy and temperature, mirrors and images, magnets, weather, modeling and technology. Some teachers even do not teach many of these topics to their pupils. It is pertinent to note therefore, that these topics are also the same where teachers do not involve their pupils in the various activities as recommended in the primary science curriculum. Furthermore, these topics are all related to the physics aspect of science. Hence, teachers who may not have been exposed to physics or integrated science, would experience difficulty in teaching such topics to their pupils. Looking at this factor from another perspective, one might venture to conclude that teachers tend to lack interest in what they do not adequately understand or may not have learnt before. This poor knowledge shown by teachers may be the root cause of their lack of interest to involve pupils in the various activities as recommended by the curriculum.

\section{Research Question 4}

Would there be significant differences in the knowledge possessed by teachers with regards their qualifications, sex and experience?

To answer this question, $\chi^{2}$ statistics was used to determine if differences exist. The result is shown in Table 3. With respect to teachers qualification, it could be seen that significant differences occur for topical areas of forces, soil, rocks and minerals, while with respect to experience, significant differences were recorded for topical areas of simple machines, magnets, solid, rocks and minerals. The message being transmitted in this result is that these content areas should be part of the training for primary school teachers. In addition, the results also indicate that the more experienced the teachers, the more they could effectively teach science. With respect to sex, there were no significant differences.

\section{DISCUSSION OF RESULTS}

The teachers' failure to utilize the various activities as suggested in the primary science curriculum has both curricula and instructional implications. Since such activities are intended as a vehicle to conceptual understanding, it would interest curriculum developers to know why primary schools teachers did not use the activities as they were intended. Curriculum developers should therefore address the following questions. Do primary school teachers feel that the activities were unnecessary? What are the problems militating against teachers in the performance of the activities in the curriculum? Could these problems be related to the supply of science materials and kits, or could it be due to lack of teachers' motivation or knowledge or practical science, or the teachers in ability to carry out the activities? Answers to these and other similar questions could be useful in selecting instruction materials and methods for teaching primary science. Two ingredients for effective science teaching in the primary schools include appropriate items of equipment and qualified science teachers. How can science be taught to pupils in a meaningful way if there are no facilities for a teacher to demonstrate a phenomenon, let alone to provide, the children with opportunity for finding out things for themselves? 
Table 3- $\chi 2$ Statistic showing Teachers' Ease or Difficulty of teaching different topics of the Primary Science Curriculum by Qualifications, Sex and Experience

\begin{tabular}{|c|c|c|c|c|c|c|}
\hline \multicolumn{7}{|c|}{ No Of Teachers Indicating } \\
\hline Topics & $\begin{array}{c}\text { Easy } \\
\text { to teach }\end{array}$ & $\begin{array}{l}\text { Difficult } \\
\text { to teach }\end{array}$ & $\begin{array}{c}\text { Never } \\
\text { Taught }\end{array}$ & $\begin{array}{c}\chi 2 \text { by } \\
\text { qualifications }\end{array}$ & $\chi 2$ by sex & $\begin{array}{c}\chi^{2} \text { by } \\
\text { Experience }\end{array}$ \\
\hline Our environment & 58 & 1 & 1 & .690 & 2.94 & 1.94 \\
\hline Using the senses & 57 & 3 & - & 3.97 & 2.28 & .939 \\
\hline Air & 51 & 8 & 1 & 5.76 & 4.96 & 3.56 \\
\hline Water & 58 & 1 & 1 & 4.55 & 2.94 & 1.94 \\
\hline Food & 60 & - & - & - & - & - \\
\hline Health and Clothing & 54 & 4 & 2 & 4.06 & 5.24 & 4.57 \\
\hline Animal & 50 & 9 & 1 & 2.94 & 1.68 & 6.13 \\
\hline Plants & 55 & 5 & - & 1.81 & 1.366 & 2.55 \\
\hline Grouping & 45 & 11 & 4 & 7.56 & 3.34 & 2.43 \\
\hline Ordering & 37 & 14 & 9 & 7.12 & 2.34 & 2.83 \\
\hline Modeling and technology & 26 & 21 & 13 & 3.66 & 4.44 & 0.286 \\
\hline Forces & 28 & 26 & 6 & 11.92 & 2.45 & 11.87 \\
\hline Measurement & 47 & 8 & 5 & 2.95 & .513 & 3.17 \\
\hline Mirros and images & 38 & 18 & 4 & 4.44 & 1.81 & 4.18 \\
\hline Sound & 49 & 7 & 4 & 1.94 & 2.01 & 9.78 \\
\hline Colour & 55 & 3 & 2 & 4.65 & 1.53 & 8.10 \\
\hline Heat Energy and temperature & 37 & 20 & 3 & 9.99 & .968 & 5.27 \\
\hline Weather & 43 & 14 & 3 & 6.13 & 4.79 & 3.38 \\
\hline Human Body & 50 & 8 & 2 & 1.79 & 2.94 & 7.99 \\
\hline Electric Circuit & 28 & 25 & 7 & 7.84 & .847 & 2.37 \\
\hline Soap and Alkali & 25 & 26 & 9 & 8.62 & .243 & 2.17 \\
\hline Simple machines & 48 & 10 & 2 & 3.12 & 1.49 & 14.86 \\
\hline Magnets & 43 & 16 & 1 & 1.08 & -466 & 15.56 \\
\hline Soil, Rocks and Minerals & 32 & 20 & 8 & 14.44 & 1.67 & 14.51 \\
\hline
\end{tabular}

When this shortcoming is coupled with the unavailability of qualified science teachers, the activities that constitute science teaching in primary science become only a matter or imagination.

\section{CONCLUSION AND IMPLICATIONS FOR THE UNIVERSAL BASIC EDUCATION SCHEME (UBE)}

The findings of this study, though not on a large scale, reveal that a significant proportion of Nigerian primary school teachers experience difficulty in teaching many of the topics of primary science. In addition, the study also shows that many of the teachers often do not involve their pupils in the various recommended activities in the science curriculum. One wonders, therefore, what type of learning experiences these teachers would be organizing for their pupils. The fact that the present teachers of primary school have difficulty in teaching the many content areas of the curriculum definitely has implications for teacher education programmes in the Universal Basic Education Scheme, which was launched on the 30th September 1999 by the Federal government of Nigeria. Many studies, such as Okeke et al (1986) and Egbegbedia (1997), have revealed that the preparation of teachers in science in our Teacher Training Institutions and Colleges of Education is quite deficient and incomprehensive. When such findings are eventually collaborated with the findings of this study, then it is inevitable and very urgent that something radical and revolutionary needs to be done to get the right standards for primary science teaching in Nigeria. The following suggestions therefore are worthy of consideration for the planners of the Universal Basic Education Scheme.

1. Primary science content should be taught as a compulsory course for three years in all teacher training colleges and colleges of education.

2. Pre-service teachers must participate in all the practical activities specified in the primary science curriculum before they are finally certificated.

3. There must be a continuous in-service training and re-training of all primary school teachers in the content area of science as well as in the acquisition of science. 
4. All primary schools should be adequately provided with funds to have science corners that are fully equipped with primary science materials, kits and improvised items. This will afford teachers the opportunity to fully engage their pupils in the various practical activities recommended in the primary science curriculum. By so doing, pupils' interests and attitudes towards science will be further generated and sustained.

\section{REFERENCES}

1. Abdulahi A (1980) Dissemination of science in African Primary Schools Problems and Prospects. Journal of Science Teachers Association of Nigeria 18(2), 20-36.

2. Aigbomian D.O (1990) Improving the attitude of Primary science teachers towards improvisation. Journal of Science Teachers Association of Nigeria, 26(2), 53-58.

3. American Association for the Advancement of Science (AAAS). (1993). Benchmarks for science literacy. New York, NY: Oxford University Press.

4. Bransford, J., Darling-Hammond, L. \& LePage, P. (2005). Introduction. In Darling-Hammond, L. \& Bransford, J. (Eds). (2005). Preparing teachers for a changing world: What teachers should learn and be able to do (pp. 1-39). San Francisco: Jossey-Bass.

5. Cochran-Smith, M. \& Lytle, S.L. (1999). Relationships of knowledge and practice: Teachers learning in communities. Review of Research in Education. 24, 249-305.

6. Egbegbedia E.A (1997) An investigation into the attitudes of primary school teachers towards improvisation in Primary Science teaching. 40th Annual Proceeding of the Science Teachers Association of Nigeria, pp. 285-289.

7. Federal Ministry Education (1981) National Policy on Education. Lagos: Federal Government Press.

8. Goodrum, D., Hackling, M., \& Rennie, L.(2001). The status and quality of teaching and learning science in Australian schools (Canberra: Department of Education, Training and Youth).

9. Harlen, W. (2000). The teaching of primary science in schools. London: David Fulham Publishers.

10. Harlen, W. \& Holroyd, C. (1997). Primary teacher understanding of concepts of science: Impact on confidence and teaching. International Journal of Science Education, 19(1), 93-105

11. Lee, O. (1995). Subject matter knowledge, classroom management and instructional practices in middle school science classrooms. Journal of Research in Science Teaching, 32(4), 423-440

12. Mullholland, J. \& Wallace, J. (1996). Breaking the cycle: Preparing elementary teachers to teach science. Journal of Elementary Science Education, 8(1), 17-38

13. Odor. I.P.S \& Azeke O.T (1981) Beyond Current Practices in improvisation in schools. Journal of Science Teachers Association of Nigeria, 25(11), 29-35

14. National Research Council. (1996). National science education standards. Washington, DC: National Academy Press.

15. Okeke E.A.C and Inomiesa. E. A. (1986). Primary science teachers' perceptions of science. Journal of Science Teachers Association of Nigeria, 25 (1) 96-104.

16. Ogunleye, A. O. (1999). Science Education in Nigeria. Lagos: Sunshine International Publications

17. Piaget Jean. (1966). Psychology of Intelligence. Tofowa: Little Fields, Adams \& Co. Osborne, J. \& Simon, S. (1996). Primary science: past and future directions. Studies in science Education, 26, 99-147

18. Poulson, L. (2001). Paradigm lost? Subject knowledge, primary teachers and education policy. British Journal of Education Studies, 49(1), 40-55.

19. Summes, M. \& Kruger, C. (1994). A longitudinal study of a constructivist approach to improving primary school teachers subject matter knowledge in science. Teaching \& Teacher Education, 10(5), 495-519

20. Summes, M., Kruger, C., Mant, J., \& Childs, A. (1998). Developing primary teachers understanding of energy efficiency. Educational Researcher, 40(3), 11-327 